\title{
HUBUNGAN KEPERCAYAAN DIRI ORANG TUA DENGAN PERKEMBANGAN ANAK USIA PRASEKOLAH DI TK ISLAM MIFTAHUL ULUM KECAMATAN DUKUHWARU KABUPATEN TEGAL
}

\author{
Khodijah $^{1}$, Susi Muryani ${ }^{2}$, Fitri Arisma Sari ${ }^{3}$ \\ Email: kaisya449@gmail.com \\ ${ }^{1,2,3}$ Prodi Sarjana Keperawatan dan Ners STIKes Bhakti Mandala Husada Slawi \\ Jalan Cut Nyak Dhien No 16 Kalisapu, Slawi, Tegal, Indonesia \\ Telp (0283) 6197570
}

\begin{abstract}
Abstrak
Kepercayaan diri orang tua merupakan persepsi orang tua yang memiliki tingkat keyakinan terhadap kemampuan dirinya dalam merawat anak dan memahami perkembangan anak. Kepercayaan diri yang baik sangat mempengaruhi tingkat perkembangan anak dalam pencapaian kesuksesan atau kegagalan. Tujuan penelitian ini adalah untuk mengetahui hubungan kepercayaan diri orang tua dengan perkembangan anak usia prasekolah di TK Islam Miftahul Ulum Kecamatan Dukuhwaru Kabupaten Tegal. Jenis Penelitian deskriptif korelasi dengan pendekatan cross sectional. Sampel berjumlah 62 ibu yang diambil dengan teknik purposive sampling. Alat yang digunakan dalam penelitian ini adalah kuesioner kepercayaan diri orang tua dan lembar observasi DDST. Hasil analisa bivariat menggunakan Spearman rank menunjukkan adanya hubungan signifikan antara kepercayaan diri orang tua dengan perkembangan anak usia prasekolah, dengan $\mathrm{p}$ value $0,000<0,05$. Penelitian ini diharapkan menjadi motivasi untuk orang tua agar lebih meningkatkan kepercayaan diri dalam merawat anak serta dapat mendorong kesuksesan perkembangan pada anak.
\end{abstract}

Kata kunci : : : kepercayaan diri orang tua, perkembangan anak

\section{Pendahuluan}

Perkembangan

merupakan

bertambahnya kemampuan individu dalam struktur dan fungsi tubuh lebih kompleks didalam perkembangan motorik, emosi, intelektual dan tingkah laku. Perkembangan motorik kasar, motorik halus harus berjalan cepat sesuai dengan tahap perkembangannya ${ }^{[1]}$

Periode penting pada tahap perkembangan yaitu tahap prasekolah dimana usia anak rentang 3- 6 tahun atau 36-72 bulan sehingga sering disebut masa keemasan. ${ }^{[2]}$ Pada masa keemasan ini anak harus mendapat perhatian yang khusus dengan dilakukan deteksi dini terhadap gangguan penyimpangan masalah keterlambatan pada perkembangan anak ${ }^{[3]}$

Prevalensi gangguan perkembangan anak sekitar $10-17 \%$ pada 25 anak, gangguan bahasa berkisar $1 \%-32 \%$, kejadian gangguan retardasi mental 3\%. Terdapat 85.779 anak usia prasekolah mengalami gangguan perkembangan. adanya penyimpangan perkembangan pada anak dapat dipengaruhi banyak faktor salah satunya pengalaman orang tua dalam merawat anak kurang percaya diri sehingga orang tua kurang dalam hal memberikan stimulasi pada anak..$^{[4]}$

Fenomena yang peneliti jumpai bahwa $65 \%$ orang tua kurang percaya diri sehingga orang tua jarang melatih anaknya menggambar dikarenakan sibuk dengan pekerjaannya, hal ini dibuktikan anak mengalami keterlambatan pada sektor motorik halus. Sedangkan prosentase $35 \%$ orang tua percaya diri, orang tua selalu melatih anaknya mewarnai, menyebutkan dua kata, melatih anak dari belajar merangkak sampai bisa berjalan sendiri dengan dibuktikan anak mampu menggambar, mewarnai serta dapat menyebutkan dua kata. Dampak kepercayaan diri orang tua baik yaitu orang tua mampu melatih, mendukung, mengajarkan anaknya untuk melakukan tugas perkembangan sehingga anak sukses di tahap perkembangannya.

Kepercayaan diri yang baik akan membuat dirinya merasa optimis Sehingga memudahkan dalam menyelesaikan suatu masalah, menghilangkan keraguan yang ada 
dipikirannya sehingga dapat mengambil keputusan yang tepat, berpikir realistis. ${ }^{[5]}$

Seorang ibu yang kurang percaya diri dalam merawat anak mungkin mengaitkan masalah dengan ketidakmampuannya sendiri. $^{[6]}$ Tujuan penelitian ini untuk mengetahui hubungan kepercayaan diri orang tua dengan perkembangan anak usia prasekolah di Taman Kanak-kanak Islam Miftahul Ulum Kab. Tegal.

\section{Metode Penelitian}

Penelitian ini merupakan penelitian kuantitatif yang menggunakan desain deskriptif korelasi dengan pendekatan cross sectional. Besar sampel dalam penelitian ini adalah 62 sampel yaitu ibu dari siswa TK Islam Miftahul Ulum, pengambilan sampel menggunakan purposive sampling. Penelitian ini menggunakan instrument kuesioner yaitu 15 pertanyaan kepercayaan diri orang tua dan lembar observasi $D D S T$. Uji asumsi menggunakan uji kolmogorovsmirnov dilakukan untuk mengetahui normalitas data.

Analisa bivariat dilakukan untuk menganalisa hubungan antara independent yaitu kepercayaan diri orang tua menggunakan skala ordinal dan dependent yaitu perkembangan anak usia prasekolah berskala ordinal. Uji statistik dalam penelitian ini yang digunakan yaitu Spearman Rank.

\section{Hasil dan Pembahasan}

Analisa bivariat digunakan untuk mengidentifikasi hubungan kepercayaan diri orang tua dengan perkembangan anak usia prasekolah. Hasil uji normalitas pada variabel diperoleh nilai signifikan $0,000<0,05$ maka dapat disimpulkan bahwa data berdistribusi tidak normal sehingga uji statistik pada penelitian adalah nonparametrik. Uji statistik bivariat yang digunakan adalah spearman rank atau spearman rho yang disajikan dalam bentuk tabel sebagai berikut:

Tabel 1 Hubungan kepercayaan diri orang tua dengan perkembangan anak usia prasekolah di TK Islam Miftahul Ulum Kecamatan Dukuhwaru Kabupaten Tegal $(\mathrm{n}=62)$

\begin{tabular}{|c|c|c|c|c|}
\hline \multirow{3}{*}{$\begin{array}{c}\text { Kepercayaan } \\
\text { diri } \\
\text { orang tua }\end{array}$} & \multicolumn{4}{|c|}{$\begin{array}{c}\text { Perkembangan anak usia } \\
\text { prasekolah }\end{array}$} \\
\hline & Normal & Suspek & $\begin{array}{l}\text { Untes } \\
\text { table }\end{array}$ & \multirow{2}{*}{$\begin{array}{c}P \\
\text { Value }\end{array}$} \\
\hline & $\mathrm{f}(\%)$ & $\mathrm{f}(\%)$ & $\mathrm{f}(\%)$ & \\
\hline Baik & $\begin{array}{l}40 \\
(64,5 \%)\end{array}$ & $\begin{array}{l}1 \\
(1,6 \%)\end{array}$ & $\begin{array}{l}0 \\
(0,0 \%)\end{array}$ & \\
\hline Kurang & $\begin{array}{l}2 \\
(3,3 \%) \\
\end{array}$ & $\begin{array}{l}18 \\
(29 \%) \\
\end{array}$ & $\begin{array}{l}1 \\
(1,6 \%)\end{array}$ & \\
\hline Total & $\begin{array}{l}42 \\
(67,8 \%) \\
\end{array}$ & $\begin{array}{l}19 \\
(30,6 \%) \\
\end{array}$ & $\begin{array}{l}1 \\
(1,6 \%)\end{array}$ & \\
\hline
\end{tabular}

Berdasarkan tabel 1 menunjukkan hasil analisis kepercayaan diri orang tua dengan perkembangan anak usia prasekolah di TK Islam Miftahul Ulum Kecamatan Dukuhwaru Kabupaten Tegal yang lebih dominan memiliki perkembangan anak normal dengan kepercayaan diri orang tua baik sebanyak 40 responden $(64,5 \%)$ sedangkan 1 responden $(1,6 \%)$ didapatkan perkembangan anak suspek, walaupun dari hasil kuesioner menunjukkan kepercayaan diri orang tua baik. Hasil uji korelasi Spearman rank diperoleh nilai $\mathrm{p}$ value $0,000<0,05$ yang berarti Ho ditolak dan $\mathrm{Ha}$ diterima, artinya ada hubungan yang signifikan antara kepercayaan diri orang tua dengan perkembangan anak usia prasekolah di TK Islam Miftahul Ulum Kecamatan Dukuhwaru Kabupaten Tegal. Jadi, semakin kepercayaan diri orang tua baik, maka perkembangan anak akan semakin normal.

Hal ini dibuktikan dari hasil kuesioner mengenai kepercayaan diri orang tua bahwa sebagian besar orang tua percaya diri dalam memberikan makanan yang baik pada anak, membantu anak memiliki rutinitas tidur yang baik, mengetahui apa yang harus dilakukan ketika anak menangis yaitu dengan cara menenangkan anak seperti membelikan permen atau mainan, serta merasa yakin bahwa suami dan keluarga selalu mendukung pada saat merawat anak.

Pada perkembangan anak normal dapat dibuktikan hasil observasi DDST sebagian besar $40(64,5 \%)$ responden menunjukkan anak lulus melakukan tugas perkembangan seperti anak dapat melakukan gosok gigi tanpa bantuan, mengambil makanan tanpa bantuan, berpakaian tanpa bantuan, mencontoh gambar lingkaran, menggambar 
orang 3 bagian, menyebutkan 1 atau 4 warna, menghitung kubus dengan benar menyebutkan 3 kegunaan, menjawab kata berlawanan 2, berdiri 1 kaki selama 1 detik, melompat dengan satu kaki, berjalan tumit kejari kaki. Hal ini disebabkan karena peran orang tua mampu memberikan stimulasi, mampu melatih atau mengajarkan anak untuk melakukan tugas perkembangannya. Ibu yang telah menjalankan peran dalam keluarga yaitu mendidik anak serta memberi stimulasi dan pelajaran untuk anak ${ }^{7}$. Anak yang banyak mendapat stimulasi yang terarah akan lebih cepat berkembang daripada anak yang kurang mendapat stimulasi. $^{[7]}$

Adapun pengaruh orang tua yang kepercayaan dirinya baik dalam memberikan makanan yang baik pada anak, bisa menenangkan anak, yakin bahwa anak baik-baik saja, tetapi tindakan orang tua masih kurang dalam memberikan stimulasi kebutuhan perkembangan anak. Sehingga masih ada yang kepercayaan diri orang tua baik, tetapi perkembangan anak masih suspek.

Hasil kepercayaan diri kurang dengan perkembangan anak normal sebanyak 2 responden $(3,2 \%)$, hal ini sesuai hasil kuesioner orang tua tidak percaya diri bagaimana bermain dengan anak, sehingga membiarkan anak belajar mandiri melakukan sesuatu tanpa bantuan dari orang lain serta kurangnya dukungan suami dikarenakan suami bekerja diluar kota. Sesuai dengan teori bahwa dukungan suami akan membantu istri mendapat kepercayaan diri sebagai seorang ibu, adanya dukungan suami membuat istri merasa lebih yakin dalam merawat anak dengan baik. ${ }^{[8]}$

Hasil analisis yang didapatkan kepercayaan diri orang tua kurang lebih dominan perkembangan anak suspek sebanyak 18 responden $(29 \%)$, hal ini sesuai dengan hasil kuesioner kepercayaan diri orang tua bahwa sebagian besar orang tua tidak percaya diri pada kemampuannya dalam merawat anak, dan kurangnya dukungan suami maupun keluarga.

Dilihat dari hasil DDST menunjukkan perkembangan anak suspek, hal ini dibuktikan anak pada sektor personal sosial yaitu anak tidak bisa atau gagal melakukan berpakaian tanpa bantuan, gagal bermain ular tangga/kartu. Sektor motorik halus yaitu anak gagal menggambar orang 3 bagian, anak gagal memilih garis yang lebih panjang, serta menolak untuk mencontoh, hal ini disebabkan orang tua cenderung tidak memperhatikan sejauh mana kemampuan yang dimiliki anaknya, pengalaman orang tua dan dilihat dari faktor lain salah satunya faktor posisi anak dalam keluarga. ${ }^{[9]}$

\section{Kesimpulan}

Terdapat hubungan yang signifikan antara kepercayaan diri orang tua dengan perkembangan usia prasekolah di TK Islam Miftahul Ulum Kecamatan Dukuhwaru Kabupaten Tegal. Orang tua diharapkan dapat memantau perkembangan anak dirumah, dan untuk TK Islam Miftahul Ulum Kecamatan Dukuhwaru Kabupaten Tegal diharapkan para guru melibatkan diri secara aktif melakukan pemeriksaan $D D S T$ sesuai usia pada anak didiknya.

\section{Daftar Pustaka}

[1] Soetjiningsih. 2013. Tumbuh Kembang Anak. Jakarta: EGC.

[2] Wong. 2008. Buku Ajar Keperawatan Pediatric Wong. Alih Bahasa: Agus Sutarna, Neti. Juniarti, H.Y. Jakarta: EGC.

[3] Depkes, RI. 2007. Pedoman Pelaksanaan Stimulasi Deteksi Intervensi Tumbuh Kembang Anak. Jakarta: Depkes RI.

[4] Depkes, RI. 2013. Riset Kesehatan Dasar. Jakarta: Depertemen Republik Indonesia.

[5] Ghufron, M.N \& Risnawita, R.S. 2010. Teori - teori Psikologi. Yogyakarta: Ar.Ruzz.

[6] Kuo, C. 2012. Parenting Confidence And Needs for Parents of Newborns in Taiwan. Iran J Pediatr. Vol. 22. No.2. Pp. 177-184.

[7] Siregar, S.D. 2011. Peran ibu bekerja dan ibu tidak bekerja terhadap pendidikan anak dirumah pada masyarakat Mandailing di Kelurahan Dolok Kecamatan Padang. Skripsi. http://respository.usu.ac.id/123 
456789/28173. Diakses tanggal 22 Oktober 2011.

[8] Sunarsih, T. 2012. Hubungan antara pemberian stimulasi dini oleh ibu dengan perkembangan balita di Taman Balita Mutia Sido Arum, Selman, Yogyakarta. Jurnal Medika Respati. Vol. 7. No. 1.

[9] Adhim, F. 2008. Indahnya Pernikahan Dini. Jakarta: Insani. 
